\title{
ANALISIS FAKTOR-FAKTOR YANG MEMPENGARUHI PEMILIHAN LOKASI TOKO MODERN DI KECAMATAN BULELENG
}

\author{
Kadek Mery Chelviani ${ }^{1}$, Made Ary Meitriana ${ }^{2}$, Iyus Akhmad Haris ${ }^{3}$ \\ Jurusan Pendidikan Ekonomi \\ Universitas Pendidikan Ganesha \\ Singaraja, Indonesia \\ e-mail: mery.chelviani@yahoo.com ${ }^{1}$, ary.meitriana@yahoo.co.id ${ }^{2}$, \\ iyus.haris@gmail.com ${ }^{3}$
}

\begin{abstract}
Abstrak
Penelitian ini bertujuan untuk mengetahui faktor-faktor yang menentukan pemilihan lokasi toko modern di Kecamatan Buleleng, dan faktor yang paling dominan mempengaruhi pemilihan lokasi toko modern di Kecamatan Buleleng. Penelitian ini merupakan penelitian deskriptif dengan pendekatan kuantitatif. Penelitian ini dilaksanakan pada 42 toko modern Kecamatan Buleleng. Data yang dikumpulkan dengan metode kuesioner, dan dianalisis dengan menggunakan teknik analisis faktor dengan bantuan Statistical Program Social Scence (SPSS) 24.0 for Windows. Hasil penelitian menunjukkan bahwa terdapat tujuh faktor yang mempengaruhi pemilihan lokasi yaitu aksesibilitas, visibilitas, tempat parkir, ekspansi, lingkungan, persaingan, peraturan pemerintah. Berdasarkan hasil analisis faktor aksesibilitas memiliki varian explained sebesar $34,838 \%$, faktor visibilitas memiliki varian explained sebesar $9,815 \%$, faktor tempat parkir memiliki varian explained sebesar $3,778 \%$, faktor ekspansi memiliki varian explained sebesar $5,032 \%$, faktor lingkungan memiliki varian explained sebesar $15,406 \%$, faktor persaingan memiliki varian explained sebesar $8,960 \%$, dan faktor peraturan pemerintah memiliki varian explained sebesar $22,171 \%$. Faktor yang paling dominan mempengaruhi pemilihan lokasi toko modern di Kecamatan Buleleng adalah faktor aksesibilitas dengan varian explained sebesar $34,838 \%$.
\end{abstract}

Kata Kunci: pemilihan lokasi, toko modern, analisis faktor

\begin{abstract}
This research aimed to know the factors that determine the selection of modern store locations in Buleleng District, and the most dominant factor influence the selection of modern store location in Buleleng District. This research was descriptive research with quantitative approach. This research was conducted in 42 modern stores Buleleng District. Data were collected through questionnaire method, questionnaires were analyzed by using factor analysis technique with Social Scence Statistical Program (SPSS) 24.0 for Windows. The results show that there are seven factors that influence the selection of the location of accessibility, visibility, parking space, expansion, environment, competition, government regulations. Based on the result of accessibility factor analysis has explained variant of $34,838 \%$, visibility factor has explained variant of $9,815 \%$, parking factor has explanation variant $3,778 \%$, expansion factor has variance explained of 5,032\% environmental factors have a explained variant of $15.406 \%$, competitive factors have explained variant of $8.960 \%$, and government regulatory factors have explained variant of $22.171 \%$. The most dominant factor influencing the selection of modern store location in Buleleng District is accessibility factor with explained variant of $34.838 \%$.
\end{abstract}

Keyword: location selection, modern store, factor analysis 


\section{PENDAHULUAN}

Pemilihan lokasi usaha harus berpatokan pada perkembangan pembangunan suatu daerah yang sering kali menimbulkan dampak baik positif maupun negatif yang dapat mempengaruhi perkembangan suatu usaha. Pemilihan lokasi sering kali dianggap sebagai hal yang sepele, akan tetapi lokasi usaha sangat menentukan keberlangsungan perusahaan. "Lokasi perusahaan merupakan kunci bagi efisiensi dan efektifitas bagi keberlangsungan perusahaan jangka panjang" (Haming, 2011). Oleh karena itu pemiihan lokasi ini harus dilakukan dan diputuskan melalui beberapa pertimbangan yang disertai fakta yang benar-benar kongkrit dan lengkap. Penentuan lokasi yang tepat akan meminimumkan biaya investasi dan operasional jangka pendek maupun jangka panjang, dan ini akan meningkatkan daya saing perusahaan (Handoko, 2000).

Lokasi sangat mempengaruhi biaya dan menentukan penghasilan, lokasi sepenuhnya memiliki kekuatan untuk membuat atau menghancurkan strategi bisnis sebuah perusahaan (Heizer \& Render, 2009). Pemilihan lokasi suatu perusahaan akan mempengaruhi risiko dan keuntungan perusahaan tersebut secara keseluruhan, mengingat lokasi sangat mempengaruhi biaya tetap maupun biaya variabel, baik dalam jangka menengah maupun jangka panjang. Sebagai contoh, biaya transportasi saja bisa mencapai $25 \%$ harga jual produk (tergantung kepada produk dan tipe produksi atau jasa yang diberikan). Hal ini berarti bahwa seperempat total pendapatan perusahaan mungkin dibutuhkan hanya untuk menutup biaya pengangkutan bahan mentah yang masuk dan produk jasa yang keluar dari perusahaan (Heizer \& Render, 2004).

Dalam situasi persaingan, faktor-

faktor lokasi dapat menjadi faktor-faktor kritis yang membuatnya sangat penting (Handoko, 2000). Faktor-faktor penting yang dipertimbangkan dalam pemilihan lokasi masing-masing usaha berbeda. Terjadinya perbedaan dalam pemilihan lokasi adalah adanya perbedaan kebutuhan masing-masing usaha. Hal ini sering disebut pendekatan situasional untuk pembuatan keputusan dinyatakan secara sederhana, (Handoko, 2000). Menurut Tjiptono (2000), terdapat banyak faktor yang mempengaruhi pemilihan lokasi usaha, ketujuh faktor yang mempengaruhi pemilihan lokasi usaha antara lain, aksesibilitas, visibilitas, tempat parkir, ekspansi, lingkungan, persaingan, peraturan pemerintah.

Dengan banyaknya pusat perbelanjaan yang didirikan maka masyarakat akan semakin mudah dalam memilih berbelanja sesuai dengan kebutuhan hidupnya. Toko-toko modern pada umumnya menyediakan barang yang telah siap dikonsumsi, dengan sarana dan prasarana yang memadai serta menyediakan jenis barang yang disukai masyarakat termasuk kebutuhan hidup sehari-hari (Sadilah dkk, 2011: 66). Toko modern di Kecamatan Buleleng telah menjadi toko yang banyak diminati para pengusaha.

Hal ini berakibat bisnis tersebut sangat maju pesat didukung dengan pengaruh pada gaya hidup masyarakat yang mengarah ke gaya hidup modern dan membutuhkan barang yang murah dengan fasilitas yang nyaman, aman dan lengkap serta prasarana. Berdasarkan data yang di peroleh dari Dinas Perdagangan dan Perindustrian Kabupaten Buleleng menunjukkan bahwa jumlah toko modern yang terdaftar dan memiliki ijin sebanyak 8 jenis toko modern dari tahun 2008 sampai 2017 yang terdapat di Kecamatan Buleleng dan sebanyak 34 toko modern yang belum terdaftar di Dinas Dinas Perdagangan dan Perindustrian Kabupaten Buleleng. Hal ini menunjukkan kehadiran toko modern oleh berbagai kalangan telah menyudutkan keberadaan pasar tradisional baik berupa pasar, kios, warung maupun toko. Keterbatasan modal, sumber daya manusia dan lemahnya keterampilan manajemen usaha membuat daya saing mereka semakin terpuruk dan tertekan oleh toko modern. Sehingga akan mengalami penurunan pendapatan, karena banyak konsumen yang lebih memilih untuk berbelanja ditoko modern dengan alasan kenyamanan dalam berbelanja.

Menurut Suwarman (2004: 280), "Lokasi merupakan tempat usaha yang 
sangat mempengaruhi keinginan seseorang konsumen untuk datang dan berbelanja". Menurut Swastha (2002: 24), "Lokasi adalah tempat dimana suatu usaha atau aktivitas usaha dilakukan". Lokasi akan mempengaruhi kedudukan perusahaan dalam persaingan dan menentukan kelangsungan hidup perusahaan tersebut.

Kesalahan dalam menentukan

lokasi akan berakibat fatal bagi suatu usaha. Menentukan lokasi tempat usaha yang strategis akan mempengaruhi kesuksesan dari bisnis yang akan dilaksanakan. Menurut Rusdiana (2014), ada enam langkah dalam menentukan lokasi usaha yaitu, pertama merumuskan sasaran pemilihan tempat kedudukan perusahaan, kedua merumuskan batas atau kendala, ketiga merumuskan normanorma keputusan, langkah keempat menghubungkan norma-norma keputusan dengan sasaran pemilihan lokasi, kelima membentuk model-model pengambilan keputusan, dan keenam menentukan lokasi terbaik. Menurut Tjiptono (2000), pemilihan tempat atau lokasi usaha memerlukan pertimbangan faktor-faktor yang cermat. Adapun tujuh faktor yang dimaksud yaitu, aksesibilitas, visibilitas, tempat parkir, ekspansi, lingkungan, persaingan dan peraturan pemerintah.

Pertama aksesibilitas misalnya lokasi yang dilalui atau mudah di jangkau sarana transfortasi umum. Untuk meningkatkan aksesibiltas dapat dilakukan dengan memperbaiki sistem transportasi seperti pelebaran jalan, pembuatan jalan baru, peningkatan layanan angkutan umum. Kedua visibilitas, yaitu lokasi atau tempat yang dapat dilihat dengan jelas dari jarak pandang normal. Ketiga tempat parkir yang luas, nyaman, dan aman, baik untuk kendaraan roda dua maupun roda empat. Ketersediaan lahan parkir merupakan fasilitas yang harus disediakan, hal tersebut diperuntukan untuk memberikan kenyamanan kosumen atau pelanggan dalam berbelanja atau berkunjung sekaligus sebagai sarana trasportasi untuk mengangkut hasil belanja. Ruang parkir yang dibutuhkan harus tersedia secara memadai. Semakin besar volume lalu-lintas yang beraktivitas baik yang meninggalkan atau menuju toko, maka semakin besar pula kebutuhan ruang parkir, bila tidak cukup kendaraan tersebut akan mengambil parkir di tepi jalan, sehingga menyebabkan kesemrawutan. Keempat ekspansi, yaitu tersedianya tempat yang cukup luas apabila ada perluasan dikemudian hari. Ekspansi adalah aktivitas memperbesar atau memperluas usaha yang ditandai dengan penciptaan perluasan fasilitas, perekrutan pegawai, dan lain-lain. Menurut Nitisemito (2004: 142) ekspansi adalah suatu tindakan yang dilakukan oleh perusahaan untuk memperbesar perusahaan dari ukuran yang lebih kecil menjadi ukuran yang lebih besar karena permintaan yang makin bertambah terhadap barang-barang atau jasa-jasanya. Perluasan atau ekspansi bisnis diperlukan oleh suatu perusahaan untuk mencapai efisiensi, menjadi lebih kompetitif, serta untuk meningkatkan keuntungan atau profit perusahaan. Kelima lingkungan, yaitu daerah sekitar yang mendukung produk yang ditawarkan. Lingkungan merupakan hal yang penting dalam berwirausaha. Jika dalam menentukan lingkungan salah memilih maka usha tersebut bisa tidak berjalan dan menghasilkan keuntungan yang maksimal. Lingkungan disatu sisi dapat menjadi peluang dari bisnis yang akan dijalankan, namun di sisi lain lingkungan juga dapat menjadi ancaman bagi perkembangan bisnis. Keberadaan bisnis dapat berpengaruh terhadap lingkungan, baik lingkungan masyarakat maupun lingkungan ekologi tempat bisnis yang akan dijalankan. Suatu bisnis dapat menimbulkan berbagai aktivitas sehingga menimbulkan dampak bagi lingkungan disekitar lokasi bisnis. Perubahan kehidupan masyarakat sebagai akibat dari adanya aktivitas semakin ramainya lokasi sekitar lokasi bisnis, timbulnya kerawanan sosial, juga perubahan gaya hidup sebagai akibat masuknya tenaga kerja dari luar daerah. Keenam persaingan, yaitu lokasi pesaing, misalnya dalam menentukan lokasi usaha, perlu mempertimbangkan apakah di jalan atau daerah yang sama banyak pula terdapat usaha yang sama. Ketujuh peraturan pemerintah adalah Peraturan Perundang-undangan di Indonesia yang ditetapkan oleh Presiden untuk menjalankan Undang-Undang sebagaimana mestinya. 
Berdasarkan Peraturan Presiden Republik Indonesia Nomor 112 Tahun 2007 Tentang Penataan dan Pembinaan Pasar, terdapat penjelasan mengenai definisi pasar modern atau toko modern. Penjelasan tersebut tertera pada pasal, Pasal 1 Ayat 5: Toko Modern ( Pasar Modern) adalah toko dengan sistem pelayanan mandiri, menjual berbagai jenis barang secara eceran yang berbentuk minimarket, supermarket, departemen store, hypermarket ataupun grosir yang berbentuk perkulakan.

Toko modern atau pasar modern adalah toko yang bersifat modern yang dimana barang dagangannya diperjual belikan dengan harga yang pas sehingga tidak ada aktivitas tawar menawar dan dengan layanan yang baik. Keunggulan toko ini yaitu tempatnya bersih dan nyaman, toko modern tidak hanya menjual kebutuhan sandang dan pangan saja, pasar tersebut juga menjual kebutuhan pokok dan sebagian besar barang dagangan yang dijualnya memiliki kualitas yang baik.

Berdasarkan Peraturan Presiden Nomor 112 Tahun 2007, didefinisikan bahwa format toko modern terbagi atas tiga kategori yaitu pertama, minimarket yaitu produk yang dijual hanya kebutuhan rumah tangga, makanan dan termasuk kebutuhan harian dengan jumlah item barang yang dijual 3000 sampai 5000 macam barang yang dijual serta ukuran toko anata 300 sampai 500 persegi. Kedua, supermarket dimana produk yang dijual adalah kebutuhan rumah tangga, makanan, dan termasuk kebutuhan seharian dengan jumlah barang yang dijual antara 5000 sampai 15000 macam barang dan ketiga, hypermarket dengan produk yang dijual adalah kebutuhan rumah tangga, makanan dan termasuk kebutuhan harian, textile, furniture.

Berdasarkan Peraturan Presiden Republik Indonesia Nomor 112 Tahun 2007 terdapat delapan ciri-ciri dari pasar modern yaitu, tidak bisa tawar-menawar harga, harga sudah tertera di barang yang dijual dan umumnya diberi barcode, barang yang dijual beranekaragam dan biasanya memiliki kualitas yang baik, berada dalam bangunan atau ruangan dan pelayanannya dilakukan sendiri (swalayan), layanan yang baik dan biasanya memuaskan, tempatnya bersih dan nyaman, ruangan ber-AC, tata tempat yang rapi supaya konsumen atau pembeli dapat dengan mudah menemukan barang yang akan di belinya, pembayarannya dilakukan dengan membawa barang ke kasir dan tentunya tidak ada tawar-menawar lagi.

Penelitian ini bertujuan untuk mengetahui faktor-faktor yang menentukan pemilihan lokasi toko modern di Kecamatan Buleleng, dan faktor yang paling dominan mempengaruhi pemilihan lokasi toko modern di Kecamatan Buleleng.

\section{METODE}

Penelitian ini merupakan jenis penelitian deskriptif kuantitatif. Penelitian ini dilakukan di Toko Modern di Kecamatan Buleleng. Populasi dalam penelitian ini adalah semua pemilik toko modern yang ada di Kecamatan Buleleng yang telah terdaftar dan memiliki ijin dari tahun 2008 sampai 2017 pada Dinas Perdagangan dan Perindustrian Kabupaten Buleleng dengan jumlah toko modern 8 jenis dan sebanyak 52 toko modern yang belum terdaftar, sedangkan sampel dalam penelitian ini adalah sebagian dari jumlah karakteristik yang dimiliki oleh populasi tersebut. Yang digunakan sebagai sampel berjumlah 8 jenis toko modern dan 34 toko modern yang belum terdaftar di Kecamatan Buleleng dari tahun 2008 sampai 2017.

Metode pengumpulan data yang digunakan dalam penelitian ini adalah dengan wawancara data yang diperoleh akan lebih mendalam, karena mampu menggali pemikiran atau pendapat secara detail. Oleh karena itu, dalam pelaksanaan wawancara diperlukan ketrampilan dari seorang peneliti dalam berkomunikasi dengan responden. Kuesioner dapat mengungkap banyak hal sehingga dalam waktu singkat diperoleh banayk data atau keterangan. Berdasarkan bentuknya, penelitian ini menggunakan kuesioner berbentuk tertutup. Kuesioner tertutup memiliki jawaban yang sudah disediakan dan tidak memberi peluang kepada responden untuk menambah keterangan lain.

Teknik analisis data yang digunakan dalam penelitian ini adalah analisis faktor. 
Analisis faktor merupakan serangkaian prosedur yang digunakan untuk mengurangi dan meringkas data tanpa kehilangan informasi penting atau meredukasi data dari variabel yang banyak diubah menjadi variabel yang jumlahnya lebih sedikit (Supranto, 2010: 113). Analisis faktor digunakan untuk meredukasi dan meringkas faktor-faktor apa saja yang menyebabkan pemilihan lokasi Toko Modern di Kecamatan Buleleng. Analisis data dilakukan dengan menganalisis jawaban dari responden atas angket yang diberikan. Hasil pengolahan data analisis faktor menggunakan perhitungan SPSS 24.0 for Windows yang akan menunjukkan fakor-faktor penyebab kesulitan dalam memilih lokasi Toko Modern di Kecamatan Buleleng.

Mengacu pada teori di atas proses pertama analisis faktor dapat dilakukan dengan tahapan Transformasi Data Ordinal ke Data Interval, sesuai dengan rumusan masalah, tujuan penelitian, dan rumusan hipotesis data dianalisis untuk mengetahui faktor-faktor yang mempengaruhi pemilihan lokasi Toko Modern di Kecamatan Buleleng. Data yang didapat dari kuesioner adalah data ordinal. Agar dapat menguji hipotesis, data tersebut harus diubah menjadi data interval melalui Method of Successive Interval (Riduwan: 2008). Proses kedua Analisis Faktor, terdapat enam langkah dalam menentukan analisis faktor pertama, merumuskan masalah, data yang diperoleh dianalisis dengan menggunakan model analisis faktor, yaitu $\mathrm{Fm}=1 \mathrm{~m} 1 \mathrm{X} 1+1 \mathrm{~m} 2 \mathrm{X} 2+\ldots .1 \mathrm{mpXp}$. Syarat, $\mathrm{m} \leq \mathrm{p}$, jika ditulis dalam bentuk matriks adalah $\mathrm{F}=1 \mathrm{X}$, dengan keterangan, $\mathrm{F}$ adalah faktor principal components (unobservable), $X$ adalah variabel yang diteliti (observable), dan 1 adalah bobot dari kombinasi linier (loading). Kedua, membuat matriks korelasi, untuk menguji ketepatan model analisis faktor, maka dapat digunakan Balett's Test of Spehercity yang dipakai untuk menguji bahwa variabelvariabel dalam sampel berkorelasi. Hasil Balett's Test of Spehercity menunjukkan apakah hubungan antara variabel-variabel signifikan atau tidak. Statistik lain yang berguna adalah pengukuran kelayakan sampel Kaiser Mayer Olkin (KMO). Analisis faktor dianggap layak jika besaran $K M O$ nilainya minimal 0,5 . Besaran lain yang dilihat adalah nilai MSA, besaran ini digunakan untuk mengukur derajat korelasi antar variabel dengan kriteria MSA $\geq 0,5$. Ketiga, menentukan jumlah factor, variabel disusun kembali berdasarkan pada korelasi hasil langkah pada butir dua untuk menentukan faktor yang dipergunakan untuk mewakili data. Untuk menentukan beberapa faktor yang dapat diterima secara empiris dapat dilakukan berdasarkan besaran eigenvalue setiap faktor yang muncul. Semakin besar eigenvalue, semakin representatif faktor tersebut untuk mewakili sekelompok variabel. Faktorfaktor yang dipilih adalah faktor yang mempunyai eigenvalue $\geq 1$ pada total varians explain. Keempat, rotasi factor, hasil penyederhanaan faktor dalam matriks faktor memperlihatkan hubungan antara faktor dengan variabel individu, tetapi dalam faktor-faktor tersebut terdapat banyak variabel yang berkorelasi sehingga sulit diinterprestasikan. Dengan menggunakan rotasi faktor matriks, matriks faktor ditrans formasikan kedalam matriks yang lebih sederhana sehingga mudah untuk diinterprestasikan. Dalam penelitian ini digunakan rotasi varimax. Kelima, Interprestasi faktor, interprestasi faktor dilakukan dengan mengelompokan variabel yang mempunyai faktor loading tinggi kedalam faktor tersebut. Untuk menginterprestasikan hasil penelitian ini, faktor loading minimal 0,5. Variabel yang mempunyai faktor loading kurang dari 0,5 dikeluarkan dari model. Keenam, Menentukan ketepatan model, tahap terakhir dari analisis faktor adalah mengetahui apakah model mampu menjelaskan dengan baik. Fenomena yang ada perlu diuji dengan teknik Principal Component Analysis (PCA) yaitu dengan melihat jumlah residual antara korelasi yang diamati dengan korelasi yang direproduksi dengan menggunakan bantuan alat hitung berupa program SPSS 24.0 for Windows.

Data yang didapat dari kuesioner sudah berupa data interval, analisis data dipakai untuk membuktikan kebenaran pengujian analisis faktor mengisyaratkan minimal data interval. Data interval diambil 
dari kuesioner, untuk setiap pertanyaan dengan menggunakan skala likert.

\section{HASIL PENELITIAN DAN PEMBAHASAN Hasil Penelitian}

Berdasarkan hasil analisis data menunjukkan bahwa faktor-faktor yang mempengaruhi pemilihan lokasi toko modern di Kecamatan Buleleng dapat dijelaskan oleh persentase dari masingmasing faktor.
Nilai Total Variance Explained digunakan untuk mengetahui persentase dari tujuh faktor yang dianalisis, yaitu aksesibilitas, visibilitas, tempat parkir, ekspansi, lingkungan, persaingan, dan peraturan pemerintah.

Hasil analisis faktor menggunakan bantuan program SPSS 24.0 for Windows pada taraf signifikansi $5 \%$, dimana persentase dari masing-masing faktor dapat dilihat pada tabel

Tabel 1. Hasil Analisis Total Variance Explained Total Variance Explained

\begin{tabular}{|c|c|c|c|c|c|c|}
\hline \multirow{2}{*}{ Component } & \multicolumn{3}{|c|}{ Initial Eigenvalues } & \multicolumn{3}{|c|}{$\begin{array}{c}\text { Extraction Sums of Squared } \\
\text { Loadings }\end{array}$} \\
\hline & Total & $\begin{array}{c}\% \text { of } \\
\text { Variance }\end{array}$ & $\begin{array}{c}\text { Cumulative } \\
\%\end{array}$ & Total & $\begin{array}{c}\% \text { of } \\
\text { Variance }\end{array}$ & $\begin{array}{c}\text { Cumulative } \\
\%\end{array}$ \\
\hline 1 & 2,439 & 34,838 & 34,838 & 2,439 & 34,838 & 34,838 \\
\hline 2 & 0,687 & 9,815 & 44,653 & & & \\
\hline 3 & 0,264 & 3,778 & 48,431 & & & \\
\hline 4 & 0,352 & 5,032 & 53,463 & & & \\
\hline 5 & 1,078 & 15,406 & 68,869 & 1,078 & 15,406 & 72,416 \\
\hline 6 & 0,627 & 8,960 & 77,829 & & & \\
\hline 7 & 1,552 & 22,171 & 100,000 & 1,552 & 22,171 & 57,009 \\
\hline icti & lod: $P$ & cipal Cor & nent Ana & & & \\
\hline
\end{tabular}

Berdasarkan tabel 1 dapat ditunjukkan bahwa faktor aksesibilitas memiliki eigenvalue sebesar 2,439 dengan nilai varian sebesar $34,838 \%$, faktor visibilitas memiliki eigenvalue sebesar 0,687 dengan nilai varian sebesar 9,815\%, faktor tempat parkir memiliki eigenvalue sebesar 0,264 dengan nilai varian sebesar $3,778 \%$, faktor ekspansi memiliki eigenvalue sebesar 0,352 dengan nilai varian sebesar 5,032\%, faktor lingkungan memiliki eigenvalue sebesar 1,078 dengan nilai varian sebesar $15,406 \%$, faktor persaingan memiliki eigenvalue sebesar 0,627 dengan nilai varian sebesar $8,960 \%$, dan faktor peraturan pemerintah memiliki eigenvalue sebesar 1,552 dengan nilai varian sebesar $22,171 \%$.

Faktor yang dapat menjelaskan pemilihan lokasi toko modern di Kecamatan Buleleng dapat ditunjukkan dengan ekstraksi faktor. Ekstraksi faktor dapat dijelaskan oleh total persentase dari masing-masing faktor utama. Faktor-faktor utama tersebut adalah aksesibilitas, peraturan pemerintah, dan lingkungan yang memiliki eigenvalue $>1$. Untuk mengetahui distribusi dimensi-dimensi yang belum dirotasi ke dalam faktor yang telah terbentuk, maka dapat dilihat pada Rotated Component Matrix. Faktor yang mampu menjelaskan pemilihan lokasi toko modern di Kecamatan Buleleng dapat dilihat pada tabel 2.

Berdasarkan tabel 2 dapat ditunjukkan bahwa faktor yang memiliki eigenvalue $>1$ adalah fakor aksesibilitas, peraturan pemerintah, dan lingkungan. Nilai varianced explained fakor aksesibilitas sebesar 34,838\%, kemudian faktor peraturan pemerintah sebesar $22,171 \%$, dan faktor lingkungan sebesar 15,406\%. Total nilai varianced explained dari ketiga faktor keseluruhan mampu menjelaskan sebesar $72,416 \%$.

Dengan demikian, $72,416 \%$ dari seluruh variabel yang ada dapat dijelaskan oleh ketiga faktor yang terbentuk. Fakor aksesibilitas memiliki varianced explained 
$34,838 \%$, artinya faktor aksesibilitas mempengaruhi pemilihan lokasi toko modern sebesar $34,838 \%$.

Fakor peraturan pemerintah memiliki varianced explained $22,171 \%$, artinya faktor peraturan pemerintah mempengaruhi

$22,171 \%$. Fakor lingkungan memiliki varianced explained $15,406 \%$, artinya faktor lingkungan mempengaruhi pemilihan lokasi toko modern sebesar 15,406\%. pemilihan lokasi toko modern sebesar

Tabel 2. Faktor yang Menjelaskan Pemilihan Lokasi Toko Modern di Kecamatan Buleleng

\begin{tabular}{lccc}
\hline \multicolumn{1}{c}{ Faktor } & Eigenvalues & Variance Explained $(\%)$ & Loading Factor \\
\hline Aksesibilitas & 2,439 & 34,838 & 0,874 \\
Visibilitas & 0,687 & 9,815 & 0,848 \\
Tempat parkir & 0,264 & 3,778 & 0,541 \\
Ekspansi & 0,352 & 5,032 & 0,760 \\
Lingkungan & 1,078 & 15,406 & 0,809 \\
Persaingan & 0,627 & 8,960 & 0,886 \\
Peraturan pemerintah & 1,552 & 22,171 & 0,930 \\
\hline
\end{tabular}

Penentuan nama faktor yang telah terbentuk untuk masing-masing faktor bersifat subjektif, sebagian besar variabel dilihat pada tabel 3 . digunakan untuk memberi nama faktor. yang memiliki nilai loading factor tertinggi

Tabel 3. Rotated Component Matrix

\begin{tabular}{cccc}
\hline Faktor & \multicolumn{3}{c}{ Component } \\
\cline { 2 - 4 } & 1 & 2 & 3 \\
\hline Aksesibilitas & 0,874 & 0,141 & $-0,136$ \\
Visibilitas & 0,848 & 0,160 & 0,130 \\
Tempat parkir & 0,541 & 0,100 & 0,476 \\
Ekspansi & $-0,035$ & $-0,119$ & 0,760 \\
Lingkungan & 0,078 & 0,068 & 0,809 \\
Persaingan & 0,236 & 0,886 & $-0,072$ \\
Peraturan pemerintah & 0,085 & 0,930 & 0,041 \\
\hline
\end{tabular}

Bedasarkan tabel 3 dapat ditunjukkan bahwa faktor yang mempengaruhi pemilihan lokasi toko modern dapat dikelompokan menjadi 3 faktor.

Faktor satu terbentuk dari faktor aksesibilitas (X1) dengan loading factor sebesar 0,874 , faktor visibilitas (X2) dengan loading factor sebesar 0,848 , dan faktor tempat parkir (X3) dengan loading factor sebesar 0,541.

Faktor dua terbentuk dari faktor persaingan (X6) dengan loading factor sebesar 0,886 dan faktor peraturan pemerintah (X7) dengan loading factor sebesar 0,930 .
Faktor tiga terbentuk dari faktor ekspansi (X4) dengan loading factor sebesar 0,760 dan faktor lingkungan (X5) dengan loading factor sebesar 0,809.

\section{Faktor yang Paling Dominan Mempengaruhi Pemilihan Lokasi Toko Modern}

Penentuan faktor yang paling dominan mempengaruhi pemilihan lokasi toko modern di Kecamatan Buleleng menggunakan parameter koefisien varimax.

Secara lebih rinci hasil ringkasan rotasi dari matriks faktor memuat nilai varimax rotation dapat dilihat pada tabel 4 . 


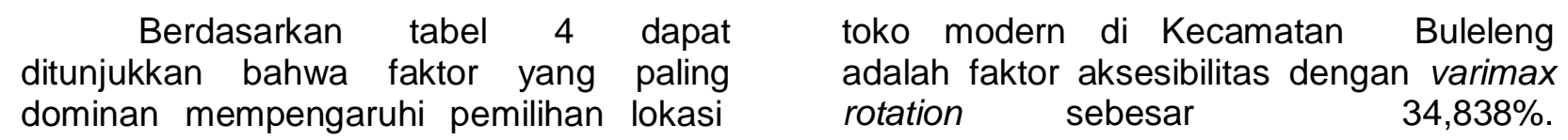

Tabel 4. Matriks Rotasi Hasil Anallisis Faktor

\begin{tabular}{l}
\multicolumn{1}{c}{ Dimensi atau Faktor } \\
\multicolumn{1}{c}{ Pemilihan Lokasi Toko Modern } \\
\hline Aksesibilitas \\
Peraturan pemerintah \\
Lingkungan
\end{tabular}

\section{Pembahasan}

Faktor-faktor yang mempengaruhi pemilihan lokasi toko modern di Kecamatan Buleleng adalah aksesibilitas, visibilitas, tempat parkir, ekspansi, lingkungan, persaingan, dan peraturan pemerintah. Hal ini sesuai dengan teori yang dikemukakan oleh Tjiptono (2000) bahwa pemilihan tempat atau lokasi usaha memerlukan pertimbangan faktor-faktor yang cermat, yaitu aksesibilitas, visibilitas, tempat parkir, ekspansi, lingkungan, persaingan, dan peraturan pemerintah. Hasil penelitian ini didukung oleh penelitian yang dilakukan oleh Sastrawan (2015), yang menyatakan bahwa faktor-faktor yang mempengaruhi pemilihan lokasi usaha adalah aksesibilitas, visibilitas, tempat parkir, ekspansi, lingkungan, persaingan, dan peraturan pemerintah. Dengan demikian untuk menjelaskan yang mempengaruhi pemilihan lokasi toko modern di Kecamatan Buleleng dapat dilihat dari faktor aksesibilitas, peraturan pemerintah, dan lingkungan.

Faktor aksesibilitas, peraturan pemerintah, dan lingkungan merupakan faktor yang paling dominan mempengaruhi pemilihan lokasi toko modern di Kecamatan Buleleng. Faktor aksesibilitas paling dominan dibandingkan faktor yang lain disebabkan karena aksesibilitas menunjukkan lokasi yang strategis dan mudah dijangkau serta waktu yang diperlukan untuk menuju lokasi toko relatif cepat.

Pemilihan lokasi toko modern yang strategis menjadi faktor penting karena konsumen akan lebih mudah menjangkau lokasi sehingga dapat mengundang

\begin{tabular}{ccc}
\multicolumn{3}{c}{ Varimax Rotation (\%) } \\
\hline$(1)$ & $(2)$ & $(3)$ \\
34,838 & - & - \\
- & 22,171 & - \\
- & - & 15,406
\end{tabular}

konsumen untuk datang ke toko. Hal ini sesuai dengan pendapat Tjiptono (2000), yang menyatakan bahwa faktor pertama pemilihan tempat atau lokasi usaha adalah aksesibilitas.

Hasil penelitian ini didukung oleh penelitian yang dilakukan oleh Sastrawan (2015), yang menyatakan bahwa faktor yang paling dominan mempengaruhi pemilihan lokasi usaha adalah faktor aksesbilitas. Hasil penelitian lainnya yang mendukung dilakukan oleh Yuliansari (2016), yang menyatakan bahwa faktor yang mempengaruhi dalam pemilihan lokasi usaha adalah faktor mudah dijangkau.

Peraturan pemerintah merupakan faktor penting dalam pemilihan lokasi usaha. Hal ini disebabkan karena lokasi toko harus memenuhi peraturan yang telah ditetapkan oleh pemerintah, yaitu lokasi toko memiliki ijin usaha. Jika lokasi usaha sangat strategis, tetapi tidak diberikan ijin usaha oleh pemerintah, maka lokasi tersebut juga tidak bisa dipilih sebagai lokasi usaha. Hal ini sesuai dengan pendapat Tjiptono (2000), yang menyatakan bahwa salah satu faktor pemilihan tempat atau lokasi usaha adalah peraturan pemerintah. Hasil penelitian ini didukung oleh penelitian yang dilakukan oleh Sastrawan (2015), yang menyatakan bahwa faktor yang paling dominan mempengaruhi pemilihan lokasi usaha adalah faktor peraturan pemerintah.

Lingkungan merupakan faktor penting dalam pemilihan lokasi usaha. Hal ini disebabkan karena lingkungan lokasi toko harus memiliki tingkat kebersihan dan kenyamanan yang baik serta lokasi berdekatan dengan pusat keramaian. Jika dalam menentukan lingkungan salah 
memilih, maka usaha tidak berjalan dengan baik sehingga menghasilkan keuntungan yang tidak maksimal. Hal ini sesuai dengan pendapat Tjiptono (2000), yang menyatakan bahwa salah satu faktor pemilihan tempat atau lokasi usaha adalah lingkungan. Hasil penelitian ini didukung oleh penelitian yang dilakukan oleh Sastrawan (2015), yang menyatakan bahwa salah faktor yang mempengaruhi pemilihan lokasi usaha adalah faktor lingkungan. Hasil penelitian lainnya yang mendukung dilakukan oleh Hadiati (2016), yang menyatakan bahwa faktor yang paling dominan berpengaruh terhadap pemilihan lokasi yang mempengaruhi kesuksesan usaha adalah lingkungan bisnis.

\section{SIMPULAN DAN SARAN Simpulan}

Berdasarkan hasil analisis data dan pembahasan, maka dapat ditarik simpulan yaitu faktor-faktor yang mempengaruhi pemilihan lokasi toko modern di Kecamatan Buleleng adalah aksesibilitas dengan nilai varian sebesar $34,838 \%$, visibilitas dengan nilai varian sebesar $9,815 \%$, tempat parkir dengan nilai varian sebesar $3,778 \%$, ekspansi dengan nilai varian sebesar $5,032 \%$, lingkungan dengan nilai varian sebesar $15,406 \%$, persaingan dengan nilai varian sebesar $8,960 \%$, dan peraturan pemerintah dengan nilai varian sebesar $22,171 \%$ danfaktor yang paling dominan mempengaruhi pemilihan lokasi toko modern di Kecamatan Buleleng adalah faktor aksesibilitas dengan varimax rotation sebesar $34,838 \%$, peraturan pemerintah dengan varimax rotation sebesar $22,171 \%$, dan lingkungan dengan varimax rotation sebesar $15,406 \%$.

\section{Saran}

Berdasarkan hasil, pembahasan, dan simpulan, maka dapat diajukan dua saran yaitu, bagi pemilik usaha dalam memilih lokasi toko modern disarankan untuk mempertimbangkan faktor aksesibilitas, contohnya seperti lokasi strategis yang mudah dijangkau oleh kendaraan umum maupun kendaraan pribadi. Kemudian perlu diperhatikan arah lalu lintas transportasi yang sering melalui lokasi toko sehingga mudah dijangkau konsumen dan jalan menuju toko dalam kondisi baik. Pemilihan lokasi juga disarankan memperhatikan jarak tempuh yang cepat dengan pusat kota sehingga banyak konsumen yang melewati toko. Bagi pemilik usaha dalam memilih lokasi toko modern juga disarankan untuk mempertimbangkan faktor peraturan pemerintah, contohnya seperti lokasi toko harus memiliki ijin usaha dari pemerintah daerah dan sudah memiliki kelengkapan serta keabsahan dokumen usaha. Bagi pemilik usaha dalam memilih lokasi toko modern juga disarankan untuk mempertimbangkan faktor lingkungan, contohnya seperti lokasi di sekitar toko bersih dan nyaman dan berada di daerah pemukiman warga sehingga banyak dikunjungi konsumen. Kemudian lokasi toko memiliki lingkungan yang kondusif dimana berada di pusat keramaian. Bagi peneliti lain yang berminat untuk mendalami mengenai faktor-faktor yang mempengaruhi pemilihan lokasi toko modern diharapkan melakukan penelitian lebih lanjut secara mendalam dengan objek yang berbeda guna keberlakuan temuan ini secara lebih luas. Selain itu, penelitian ini perlu dikembangkan dengan mengkaji faktorfaktor lain yang mempengaruhi pemilihan lokasi usaha.

\section{DAFT AR PUSTAKA}

Hadiati, Ayu. 2016. Analisis Faktor-faktor Pemilihan Lokasi yang Mempengaruhi Kesuksesan Usaha (Studi Kasus: Pedagang Handphone Sepanjang Jalan Moses). Skripsi tidak diterbitkan. Yogyakarta: Universitas PGRI

Handoko, T. Hani. 2000. Manajemen Personalia dan Sumber Daya Manusia, Edisi Kedua, BPFE: Yogyakarta.

Haming, M., \& Mahmud Nurnajamuddin. 2011. Manajemen Produksi Modern Operasi Manufaktur dan Jasa. Jakarta: Bumi Aksara.

Heizer, Jay \& Barry Render. 2004. Manajemen Operasi. Buku 2. Edisi 7. Jakarta: Salemba Empat. 
2009. Manajemen Operasi. Buku

1. Edisi 9. Jakarta: Salemba Empat.

Nitisemito, Alex S. 2004. Manajemen Personalia. Jakarta: Ghalia Indonesia.

Peraturan Presiden Republik Indonesia Nomor 112 Tahun 2007 Tentang Penataan dan Pembinaan Pasar Tradisional Pusat Perbelanjaan Dan Toko Modern

Riduwan. 2008. Rumus dan Data dalam Analisis Statistika. Bandung: Alfabeta.

Rusdiana, M., \& Moch Irfan. 2014. Sistem Informasi Manajemen. Bandung: Pustaka Setia.

Sadilah, Emiliana, dkk. 2011. Eksitensi Pasar Tradisional (Relasi dan Jaringan Pasar Tradisional di Kota Semarang- Jawa Tengah). Yogyakarta: Penerbit BPSNT.

Sastrawan. 2015. Analisis Faktor-Faktor Yang Mempengaruhi Pemilihan Lokasi Usaha Pedagang Kaki Lima Di Pantai Penimbangan Kecamatan Buleleng. Skripsi tidak diterbitkan. Singaraja: UNDIKSHA

Supranto, J. 2010. Statistika. Jakarta: Erlangga.

Suwarman. 2004. Prilaku Konsumen. Jakarta: Ghalia Indonesia.

Swastha, Basu. 2002. Manajemen Pemasaran. Edisi Kedua. Cetakan Kedelapan. Jakarta: Penerbit Liberty.

Tjiptono, Fandy. 2000. Strategi Pemasaran Edisi 3. Yogyakarta: Penerbit Andi Offset.

Yuliansari, Elsi. 2016. Strategi Pemilihan Lokasi Terhadap Kesuksesan Usaha Jasa Mikro-Kecil di Kecamatan Jekan Raya. Skripsi tidak diterbitkan. Palangka Raya: Institut Agama Islam Negeri Palangka Raya. 